\title{
Sinyalize Kavşaklarda Doygun Akım Değerinin İrdelenmesi
}

\author{
S. Pelin ÇALIŞKANELL $\dot{i}^{1}$ \\ Serhan TANYEL ${ }^{2}$
}

$\ddot{O} \mathbf{z}$

Kavşakların başarımının, bölgesel gözlemler olmadan, çeşitli öngörülen/varsayılan değerler kullanılarak yapılan analizlerle değerlendirilmesi gerçekçi sonuçlar vermemektedir. Çalışmanın ana amacı sinyalize kavşakların kapasitesinin belirlenmesinde en önemli parametrelerden biri olan doygun akım değerinin araştırılmasıdır. Çalışmada, İzmir, Bursa ve Denizli kent merkezlerindeki toplam on kavşaktan elde edilen verilerden yararlanarak; 1şıklı (sinyalize) kavşaklar için temel (ideal) doygun akım değeri ile doygun akımı etkileyen bazı düzletme faktörlerine ait parametreler önerilmeye çalışılmıştır. Analizler, temel doygun akım değerinin 1720 otomobil/saat/şerit gibi düşük bir değer olduğunu; 1şıklı dönel kavşaklarda ise bu değerin 1634 otomobil/saat/şerit'e düştügünü göstermiştir. Çalışmada ayrıca ağır araçlar, sola ve sağa dönen araçlar için "Eşdeğer Otomobil Birim" değerleri önerilmiştir.

Anahtar Kelimeler: Sinyalize kavşaklar, doygun akım, sinyalize yuvarlakada kavşak, eşdeğer otomobil birimi.

\begin{abstract}
Investigation of Saturation Flow Value at Signalized Intersections

Determination of the performance of intersections by using hypothetical or default values without regional observations may lead to unrealistic results. The main goal of this study is to investigate the ideal saturation flow value which is one of the most important parameters in predicting capacity of signalized intersections. In this study, values for ideal saturation flow and parameters of various correction factors were recommended by using the observations obtained from 10 signalized intersections from İzmir, Bursa and Denizli provinces. Analyses have shown that, ideal saturation flow value for signalized intersections can be a rather low value such as 1720 passenger cars/hr/lane, dropping to $1634 \mathrm{veh} / \mathrm{hr} / \mathrm{lane}$ for signalized traffic roundabouts. Furthermore, passenger car equivalence values for heavy, right turning and left turning vehicles were also suggested.
\end{abstract}

Keywords: Signalized intersections, saturation flow, signalized traffic circles, passenger car equivalent.

\footnotetext{
Not: Bu yaz1

- Yayın Kurulu'na 08.03.2016 günü ulaşmıştır. 18.04.2017 günü yayımlanmak üzere kabul edilmiştir.

- 31 Mart 2018 gününe kadar tartışmaya açıktır.

- DOI: $10.18400 /$ tekderg.346592

1 Dokuz Eylül Üniversitesi, İnşaat Mühendisliği Bölümü, İzmir - pelin.caliskanelli@deu.edu.tr

2 Dokuz Eylül Üniversitesi, İnşaat Mühendisliği Bölümü, İzmir - serhan.tanyel@deu.edu.tr
} 
Sinyalize Kavşaklarda Doygun Akım Değerinin İrdelenmesi

\section{GíRiş}

Doygun akım, 1şıklı (sinyalize) bir kavşakta 1 şı yeşile döndükten sonra en fazla boşaltılabilecek olan araç sayısıdır. Başka bir ifade ile kavşak kolunda sürekli bir kuyruk bulunması ve 1şı̆̆ın bir saat süreyle yeşil yanması durumunda bir şeritten geçebilecek olan en yüksek araç sayısıdır [1]. Şekil 1' de görülebileceği gibi ilk aracın arkasında hareket eden araçların takip aralığı değerinin ikinci araçtan itibaren düşmeye başladığı ve yaklaşık altıncı araçtan itibaren sabit kaldığı söylenebilir [2]. Araçlar arasında sabit kaldığı kabul edilen ve kavşaktan bir saat içinde geçirilebilecek olan en yüksek araç sayısını belirlemek amacıyla kullanılan bu sabit değere doygun takip aralığı adı verilir. Doygun takip aralığına bağlı olarak, doygun akım değeri;

$$
S=3600 / h_{n}
$$

şeklinde hesaplanır. Burada $\mathrm{S}$; doygun akım (araç/saat/şerit), $\mathrm{h}_{\mathrm{n}}$; ortalama doygun takip aralığı (saniye) dır

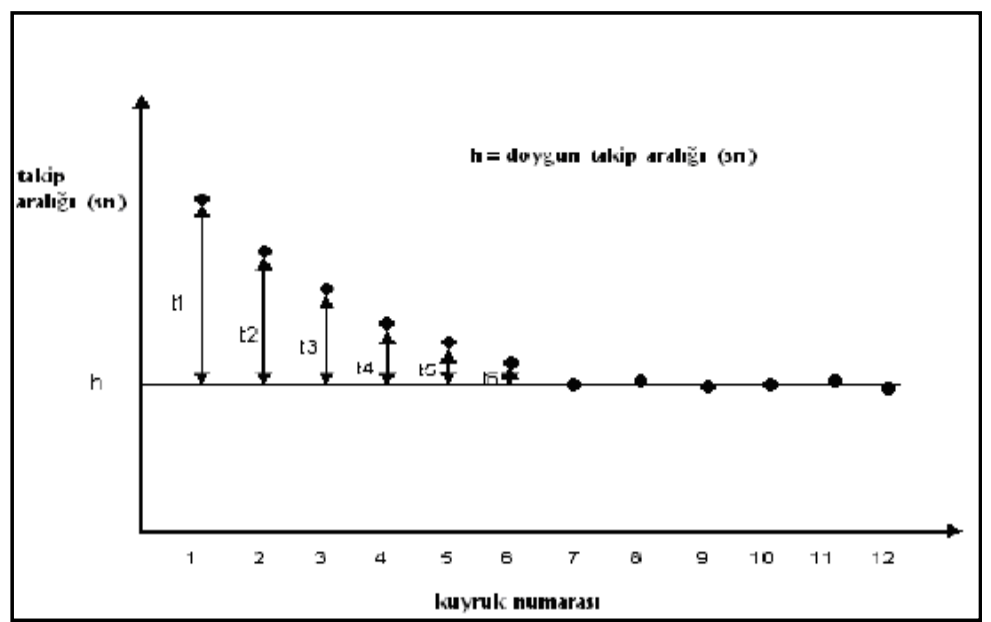

Şekil 1. Kuyruk numarasına bă̆lı olarak takip aralı̆̆ değerlerinin değişimi [2]

Doygun akım, başlangıç gecikmesine uğrayan araçlar ve doygun takip aralığ 1 değerine bağlı olarak belirlenen bir kavramdır. Bölgesel gözlemler olmadan, çeşitli yöntemlerde öngörülen/varsayılan değerler kullanılarak yapılan analizler çoğunlukla ışıklı kavşak sistemlerinin başarımının değerlendirilmesinde gerçekçi sonuçlar vermemektedir [3]. Her ülkede hatta şehirde şerit kullanımı, şerit kapasitesi, araç takip aralığı ve sürücü davranışı gibi faktörler değişkendir [4]. Bu sebeplerle, çeşitli araştırmacılar, yaptıkları çalışmalarla farklı ülkelerde kullanılmak üzere geçerli olabilecek doygun akım değerini belirlemeye çalışmışlardır. Nıtttymaki ve Pursula [5], çalışmalarında çeşitli ülkelerde kullanılmakta olan temel doygun akım değerlerinin 1800 2475 otomobil/saat/şerit aralığında değişebildiğini 
belirtmişler ve kendi ülkelerinde kullanılmakta olan temel doygun akım değerini (doğru giden araçlar için) 1940 otomobil/saat olarak güncellemişlerdir.

Her ne kadar, doygun takip aralığına altıncı araçtan sonra erişildiği düşünülmekteyse de son yıllarda yapılan araştırmalar, kuyruk uzunluğu arttıkça takip aralığı değerinin düştüğünü göstermektedir [6,7]. Joseph ve Chang [8] çalışmalarında doygun takip aralığı değerine 3'üncü ile 7'nci araçtan itibaren ulaşııldığını bulmuş; buna bağlı olarak doygun akım değerinin de 1900 ile 2200 otomobil/saat arasında değiştiğini belirlemişlerdir. Rahman ve diğerleri [9], inceledikleri kavşaklar için doygun akım rejiminin tek şeritli yollarda kuyruktaki 4'üncü araçta, iki şeritli yollarda, iç şeritte 3'üncü araçta, dış şeritte 5'inci araçta, üç şeritli yollarda ise doygun akım rejiminin 3'üncü, 5'inci ve 6'ncı araçtan itibaren başladığını bulmuşlardır.

Ülkemizde doygun akım üzerine yapılan önemli çalışmalardan birinde Çetin ve Murat [10], doygun akımın hesaplanması için sürücü davranışına bağlı bir matematiksel model önermişlerdir. Çalışmalarında tek bir kavşakta yaptıkları gözlemler, 1şıklı kavşaklarda sol şeritteki doygun akım değerinin 1765 1784 otomobil/saat; orta şeritte 1603 1628 otomobil/saat ve sağ şeritte ise 1111 1126 otomobil/saat aralığında değiştiğini göstermiştir. Çalışma kapsamında önerilen bağıntıyı kullanarak farklı hız, ivme ve araç uzunlukları için doygun akım değerinin 732 4330 otomobil/saat aralığında değişebileceğini hesaplamışladır. Burada 4330 otomobil/saat değerinin kuramsal bir değer olduğu unutulmamalıdır. Özdemir [11] tarafından yapılan diğer bir çalışmada ise, İstanbul'daki üç kavşakta yapılan gözlemler sonucunda, temel doygun akım değeri 1891 otomobil/saat/şerit olarak bulunmuştur. Ülkemizde yapılan diğer bir çalışmada ise Çalışkanelli v.d. [12], İzmir kentinde yapılan gözlemlerden ışıklı kavşaklarda kuyrukta ilk sırada bekleyen sürücülerin başlangıç tepki sürelerinden yola çıkarak temel doygun akım değerini 1722 otomobil/saat olarak hesaplamışlardır. Çalışkanelli ve Tanyel [13] ise çalışmalarında, ışıklı bir kavşak yaklaşımında kuyrukta bekleyen araçlar pozisyon numaralarına göre ele alındıklarında; kuyrukta bekleyen ilk sıradaki araçlar haricindeki araçların takip aralıklarında istatistiksel olarak anlamlı bir farklılık belirlenemediğini görmüşlerdir. Bu sonuç, kuyrukta ilk sırada bekleyen sürücülerin kavşak başarımındaki önemini ortaya koymaktadır. Çalışkanelli ve Tanyel [13] aynı çalışmada, temel doygun akım değerinin 1650 otomobil/saat/şerit olabileceğini belirtmiş̧lerdir.

Çalışmada, temel doygun akım değeri için bir tartışma ortaya konması hedeflenmiştir. Bu amaçla İzmir'den sekiz, Bursa'dan bir ve Denizli'den bir kavşak olmak üzere toplam on kavşakta yapılmış olan gözlemlerden yararlanılmıştır. Çalışma kapsamında, ağır araç, sola ve sağa dönen araçların etkilerinin yanı sıra ışıklı yuvarlakada kavşakların etkileri üzerinde de durulmaya çalışılmışıtır.

\section{GÖZLEM VERILERININ ELDE EDILLMESI}

Çalışma kapsamında, İzmir kent merkezinde sekiz, Bursa'da ve Denizli'de birer olmak üzere toplam on kavşakta gözlemler yapılmıştır. Kavşaklara ait bazı geometrik özellikler ile, saatlik trafik hacim ve devre süresi ile ilgili bilgiler Tablo 1'de sunulmuştur.

Gözlemler, hafta içi zirve saatlerde video kamera kullanılarak kavşak yakınındaki yüksek bir binadan gerçekleştirilmiş; kamera kayıtları daha sonra büro ortamında, veriler arasında 
gözlemcilerden kaynaklanabilecek farklılıkları en aza indirgemek amacıyla, tek bir gözlemci tarafindan izlenerek veriler elde edilmiştir. Gözlemlerde, her bir devre süresi için ilk olarak trafik ışı̆̆ının yeşile döndüğü an kaydedilmiş; bu işlemin ardından her aracın arka tamponlarının kavşak DUR çizgisini geçiş süreleri tespit edilmiş ve boşaltım aralıkları hesaplanmıştır. Analizlerde kuyruk uzunluklarının şerit başına 8 araç/devre'den daha uzun olduğu veri grupları kullanılmıştır. Toplamda analizlerde kullanılabilecek 516 veri grubu elde edilebilmiştir. Gözlem yapılan kavşaklarda ayrıca, her bir devrede gözlemlenen araç kompozisyonu, sola ve sağa dönüş yapan araç sayıları ile her bir şeritteki kuyruk uzunluğu verileri de toplanmıştır.

Tablo 1. Gözlem yapılan kavşak yaklaşımlarına ait bilgiler

\begin{tabular}{|c|c|c|c|c|c|c|c|c|}
\hline Kavşak Adı & Yaklaşım Kolu & Şerit Sayıs & $\begin{array}{c}\text { Şerit } \\
\text { Geniş liği } \\
\text { (m) }\end{array}$ & $\begin{array}{c}\text { Dönüş } \\
\text { Şe ridi Tipi } \\
\text { ve } \\
\text { Genişliği } \\
* *\end{array}$ & $\begin{array}{c}\text { Yaklaşım } \\
\text { hacmi } \\
\text { (araç/saat) }\end{array}$ & $\begin{array}{c}\text { Ortlama } \\
\text { Kuyruk } \\
\text { Uzunluğu } \\
\text { (araç/şerit) }\end{array}$ & $\begin{array}{c}\text { Devre } \\
\text { süresi } \\
\text { (saniye) }\end{array}$ & $\begin{array}{c}\text { Gözlem } \\
\text { Sayısı }\end{array}$ \\
\hline \multirow{3}{*}{ Lunapark (İzmir) } & $\begin{array}{l}\text { Girne Bulv. Kuzey } \\
\text { Yaklaşımı }\end{array}$ & 2 & 3,30 & $\begin{array}{l}\text { Sola Dönüş } \\
60 \mathrm{~m}\end{array}$ & 2446 & 17,0 & \multirow{3}{*}{105} & 51 \\
\hline & $\begin{array}{l}\text { Gürne Bulv. Güney } \\
\text { Yaklaşımı }\end{array}$ & 2 & 3,40 & $\begin{array}{l}\text { Sağa Dönüşs } \\
30 \mathrm{~m}\end{array}$ & 1096 & 10,3 & & 21 \\
\hline & Atatürk Bulvarı & 2 & 3,50 & & 574 & 9,8 & & 25 \\
\hline $\begin{array}{l}\text { Balçova Çağdaş } \\
\text { Taksi (İzmir) * }\end{array}$ & $\begin{array}{l}\text { Mithat Paşa Cad. } \\
\text { Doğu Yaklaşımı }\end{array}$ & 3 & 3,50 & & 1684 & 8,0 & 95 & 59 \\
\hline Çankaya (İzmir) & Fevzi Paşa Bulvarı & 3 & 3,60 & & 1635 & 9,9 & 86 & 40 \\
\hline $\begin{array}{l}\text { Bornova Adliye } \\
\text { (İzmir) } *\end{array}$ & $\begin{array}{l}\text { Haydar Aliyev Bulv. } \\
\text { Özkanlar Yaklaşımı }\end{array}$ & 3 & 3,00 & & 1567 & 7,4 & 76 & 15 \\
\hline $\begin{array}{l}\text { Atatürk Anadolu } \\
\text { Lisesi (Bursa) }\end{array}$ & $\begin{array}{l}\text { Stadyum Cad. Kuzey } \\
\text { Yaklaşımı }\end{array}$ & 2 & 3,25 & & 1090 & 9,7 & 88 & 72 \\
\hline \multirow{2}{*}{ Cin Deresi (izmir) } & $\begin{array}{l}\text { Mithat Paşa Cad. } \\
\text { Doğu Yaklaşımı }\end{array}$ & 2 & 3,20 & $\begin{array}{l}\text { Sola Dönüş } \\
50 \mathrm{~m}\end{array}$ & 1413 & 9,2 & \multirow{2}{*}{85} & 15 \\
\hline & $\begin{array}{l}\text { Mithat Paşa Cad. Batı } \\
\text { Yaklaşımı }\end{array}$ & 2 & 3,20 & & 759 & 6,1 & & 15 \\
\hline \multirow[t]{2}{*}{ Vali Konağı (İzmir) } & $\begin{array}{l}\text { Mustafa Kemal Sahil } \\
\text { Bulv. Doğu Yaklaşımı }\end{array}$ & 3 & 3,60 & $\begin{array}{c}\text { Sola Dönüş } \\
75 \mathrm{~m} \\
\end{array}$ & 3559 & 11,7 & \multirow[t]{2}{*}{70} & 50 \\
\hline & $\begin{array}{l}\text { Mustafa Kemal Sahil } \\
\text { Bulv. Batı Yaklaşımı }\end{array}$ & 3 & 3,60 & & 2067 & 10,9 & & 17 \\
\hline Rektörlük (İzmir) & $\begin{array}{l}\text { Cumhuriyet Bulv. } \\
\text { Güneybatı Yaklaşımı }\end{array}$ & 2 & 3,25 & & 1588 & 9,15 & 70 & 35 \\
\hline Yunuslar (İzmir) * & $\begin{array}{l}\text { Girne Bulv. Kuzey } \\
\text { Yaklaşımı }\end{array}$ & 2 & 3,65 & & 540 & 6,3 & 75 & 50 \\
\hline Pekdemir (Denizli)* & Pekdemir Yaklaşımı & 3 & 3,5 & & 1228 & 8,85 & 96 & 51 \\
\hline
\end{tabular}

** Sola ve sağa dönüş cepleri, yaklaşım şerit sayısına dahil değildir.

Sinyalize kavşak kapasite ve hizmet düzeyi hesaplarında en etkin parametre olan doygun akımın belirlenmesi ile ilgili olarak yapılmış olan birçok çalışma ve kullanılan farklı yöntemler bulunmaktadır. Yöntemlerin hepsinde doygun akım oranının doygun yeşil süre içinde sabit olduğu kabul edilmektedir [14]. Bu yöntemlerden en çok kabul görenlerden bir tanesi "takip aralı̆̆ı" yöntemidir. Takip Aralığı Yönteminde; sinyal yeşile döndüğünde, ilk sırada bekleyen birkaç araç göz ardı edilerek kuyruktan boşalan araçların, sinyal-dur 
çizgesindeki ortalama takip aralığı değeri hesaplanır. Doygun akım değeri, hesaplanan ortalama takip aralığına bağlı olarak belirlenir $[14,15]$.

Takip aralığı yönteminin benimsendiği ve doygun akım değerinin belirlenmesinde en yaygın olarak kullanılan hesap süreçlerinden birisi HCM 2010 yöntemidir [1]. Bu yöntemde sinyal çizgisinde beklemekte olan araçların takip aralıklarının dördüncü sıradaki araçtan sonra istikrarl1/sabit düzeye geldiği kabul edilir. HCM 2010'e göre araçlar arasındaki doygun takip aralığı aşağıdaki şekilde hesaplanabilir:

$$
h_{n}=\frac{\sum_{i=1}^{m} \sum_{j=5}^{n} h_{i j}}{\sum{ }_{i=1}^{m}\left(n_{i}-4\right)}
$$

Burada, $h_{n}$; doygun takip aralığ 1 (saniye), $h_{i j}$; i. devrede, kuyruktaki j. aracın kuyruğu boşaltma takip aralığı (saniye), $n_{i}$; i. devrede kuyruktaki araç sayısı $\left(n_{i}>4\right), m$; gözlemlenen devre sayısıdır. Tablo 2'de analizlerde kullanılan veri tablosuna ait bir örnek görülmektedir.

\begin{tabular}{|c|c|c|c|c|c|c|c|c|c|c|c|}
\hline$\underset{\text { (taşıt } / \text { saat) }}{\text { Hacim }}$ & $\begin{array}{l}\text { Devre } \\
\text { Süresi }\end{array}$ & Yeşil Süre & $\begin{array}{c}\text { Şerit } \\
\text { Genişliği }\end{array}$ & $\%$ minibüs & $\%$ otobüs & \% kamyon & $\begin{array}{c}\text { Sağa } \\
\text { Dönüşs } \\
\text { Oranı (\%) }\end{array}$ & $\begin{array}{c}\text { Sola } \\
\text { Dönüs } \\
\text { Oranı (\%) }\end{array}$ & $\begin{array}{c}\text { Yuvarlaka } \\
\text { Ada }\end{array}$ & $\begin{array}{c}\text { Kuyruk } \\
\text { uzunluğu }\end{array}$ & $\begin{array}{c}\text { Doygun } \\
\text { Akım } \\
\text { (taşıt/saat) }\end{array}$ \\
\hline 663 & 70 & 43 & 3,50 & 0,08 & 0,23 & 0,00 & 0,00 & 0,00 & 0,00 & 13 & 1530,76 \\
\hline 546 & 86 & 39 & 3,00 & 0,08 & 0,23 & 0,00 & 0,00 & 0,00 & 0,00 & 11 & 1321,72 \\
\hline 630 & 86 & 39 & 3,00 & 0,00 & 0,20 & 0,13 & 0,00 & 0,00 & 0,00 & 11 & 1308,89 \\
\hline 410 & 88 & 40 & 3,30 & 0,00 & 0,20 & 0,00 & 0,09 & 0,00 & 0,00 & 11 & 1586,02 \\
\hline 375 & 95 & 50 & 3,40 & 0,10 & 0,00 & 0,00 & 0,00 & 0,89 & 1,00 & 10 & 1399,78 \\
\hline 675 & 95 & 50 & 3,40 & 0,00 & 0,00 & 0,00 & 0,00 & 0,89 & 1,00 & 10 & 1570,11 \\
\hline 788 & 95 & 50 & 3,40 & 0,00 & 0,00 & 0,00 & 0,00 & 0,77 & 1,00 & 10 & 1372,65 \\
\hline 462 & 86 & 39 & 3,00 & 0,00 & 0,27 & 0,09 & 0,00 & 0,00 & 0,00 & 10 & 974,95 \\
\hline 450 & 95 & 50 & 3,40 & 0,00 & 0,00 & 0,00 & 0,00 & 0,82 & 1,00 & 9 & 1528,53 \\
\hline 375 & 95 & 50 & 3,40 & 0,00 & 0,00 & 0,00 & 0,00 & 0,83 & 1,00 & 9 & 1373,42 \\
\hline 713 & 95 & 50 & 3,40 & 0,11 & 0,00 & 0,00 & 0,00 & 0,80 & 1,00 & 9 & 1849,95 \\
\hline 713 & 95 & 50 & 3,40 & 0,22 & 0,00 & 0,00 & 0,00 & 0,72 & 1,00 & 9 & 1714,29 \\
\hline 588 & 86 & 39 & 3,00 & 0,00 & 0,23 & 0,08 & 0,00 & 0,00 & 0,00 & 9 & 1622,64 \\
\hline 462 & 86 & 39 & 3,00 & 0,00 & 0,27 & 0,00 & 0,00 & 0,00 & 0,00 & 9 & 1570,68 \\
\hline 288 & 75 & 21 & 3,30 & 0,00 & 0,00 & 0,00 & 0,88 & 0,12 & 1,00 & 8 & 1492,38 \\
\hline 240 & 96 & 21 & 3,30 & 0,20 & 0,00 & 0,00 & 1,00 & 0,00 & 1,00 & 8 & 1140,32 \\
\hline 600 & 95 & 50 & 3,40 & 0,13 & 0,00 & 0,00 & 0,34 & 0,00 & 1,00 & 8 & 1651,75 \\
\hline
\end{tabular}

\section{TEMEL (IDEAL) DOYGUN AKIM DEĞERI}

Doygun akım, hesaplamalarda kullanılırken inceleme yapılan kavşak yaklaşımındaki trafik akım ve yönetim özelliklerine, akım içerisindeki ağır araç oranına, şerit özelliklerine, topoğrafik özelliklere, yaya hareketliliğine ve kavşağın bulunduğu bölgenin özelliklerine bağlı olarak çeşitli düzeltme faktörleri ile çarpılarak düzeltilir [1]. Kapasite analizlerinde kullanılan temel doygun akım değeri HCM 2000'e göre uygun (ideal) şartlar altında 1900 otomobil/saat/şerit olarak kabul edilmektedir [16]. HCM2010'da ise nüfusu 250000 'i aşan kentlerde temel doygun akım değeri 1900 otomobil/saat/şerit; diğer kesimlerde ise 1750 otomobil/saat/şerit olarak önerilmektedir [1]. Ancak uygun şartların geçerli olmadığı pratik 
şartlar altında bu değer aşağıdaki bağıntı yardımıyla düzeltilerek kullanılır. Işıklı kavşaklarda bir şerit grubuna ait doygun akım değeri aşağıdaki bağıntı yardımıyla hesaplanabilir [1]:

$$
S=S_{o} \times N \times f_{w} \times f_{H V} \times f_{g} \times f_{p} \times f_{L U} \times f_{b b} \times f_{a} \times f_{R T} \times f_{L T} \times f_{L p b} \times f_{R p b}
$$

Burada $S$; doygun akım oranı, $\mathrm{S}_{o}$; temel doygun akım değeri, $N$; şerit sayısı, $f_{w}$; şerit genişlik faktörü, $f_{H V}$; ağır araç düzeltme faktörü, $f_{g}$; yaklaşım kolu eğim düzeltme faktörü, $f_{p}$; parklanma düzeltme düzeltme faktörü, $f_{L U}$; şerit kullanım oranı faktörü, $f_{b b}$; otobüs durağ etkisi düzeltme faktörü, $f_{a}$; bölge tipi faktörü, $f_{R T}$; sağa dönüş düzeltme faktörü, $f_{L T}$; sola dönüş düzeltme faktörü, $\mathrm{f}_{L p b}$; sola dönüşler için yaya düzeltme faktörü, $f_{R p b}$; sağa dönüşler için yaya düzeltme faktörüdür.

Çalışma kapsamında yapılan analizlerin ilk adımı olarak, temel doygun akım değerinin hesaplanması amaçlanmıştır. $\mathrm{Bu}$ amaçla aşağıda belirtilen özellikleri taşıyan veriler kullanılmıştır:

1. Kuyrukta hiç ağır araç yer almamaktadır.

2. Kuyrukta sağa veya sola dönüş yapan araç yer almamaktadır.

3. İncelenen şerit, yuvarlak ada sinyalize bir kavşakta yer almamaktadır.

4. Kavşağa yakın bir mesafede (100 m'den yakın) otobüs durağı yer almamaktadır.

5. Yol kenarında park hareketi yoktur.

6. İncelenen devrede yaya hareketi yoktur veya ihmal edilebilecek düzeydedir.

7. Eğim değeri \%1'in altındadır.

8. Şerit genişliği 3,0 3,6 metre'dir.

9. 8 otomobil/şerit/devre'den daha kısa kuyruk uzunlukları dikkate alınmamıştır.

Temel doygun akımın tespit edilebilmesi için yukarıdaki özelliklere sahip toplam 100 (yüz) veri, Çankaya, Rektörlük, Atatürk Anadolu Lisesi ve Vali Konağı kavşaklarından elde edilebilmiştir. Verilerin elde edilmesinde Bölüm 2'de açıklanan HCM2010 yöntemi kullanılmıştır. Bu dört kavşağa ait doygun takip aralığı değerleri ile ilgili tanımlayıcı istatistikler ve varyans analizi sonuçları Tablo 3'te görülmektedir.

Tablo 3. Doygun takip aralığı değerleri ile ilgili tanımlayıcı istatistikler ve varyans analizi sonuçları

Doygun Takip Aralığı (saniye)

Kavşak Adı Ortalama Std. Sap. En Küçük En Büyük

\begin{tabular}{|c|c|c|c|c|c|c|}
\hline Kavşak Adı & Ortalama & Std. Sap. & En Küçük & En Büyüh & Varyans & Analizi \\
\hline Çankaya (İzmir) & 2,08 & 0,30 & 1,70 & 2,58 & Ser. Der. & 3 \\
\hline Atatürk Anadolu Lisesi (Bursa) & 2,03 & 0,25 & 1,50 & 2,43 & HKT & 0,27 \\
\hline Vali Konağı (İzmir) & 2,11 & 0,39 & 1,59 & 2,94 & $\mathrm{OKH}$ & 0,09 \\
\hline Rektörlük (İzmir) & 2,07 & 0,27 & 1,55 & 2,81 & Fist. & 0,86 \\
\hline Tüm veriler & 2,088 & 0,32 & 1,50 & 2,94 & $\mathrm{P}$ & 0,46 \\
\hline
\end{tabular}

HKT, hata kareleri toplami; OKH, ortalama karesel hatayl tanimlamaktadir. 
Tabloda tüm verilerin ortalaması olarak bulunmuş olan 2,088 saniye doygun takip aralığ değeri kullanılarak; temel doygun akım değerinin ortalama 1724 araç/saat/şerit alınabileceği görülmektedir. Bu değer, Çalışkanelli v.d. [12] tarafindan bulunmuş olan 1722 araç/saat/şerit değerine çok yakındır. Çalışkanelli v.d.[12] kuyrukta ilk sırada bulunan sürücülerin başlangıç tepki sürelerinin ortalamasının 1,39 saniye, standart sapmasının ise 0,93 olduğunu hesaplamışlardır. Akçelik v.d. [17], başlangıç tepki süresi değeri kullanılarak doygun akım takip aralığı değerinin aşağıdaki bağıntıdan elde edilebileceğini önermişlerdir:

$$
h_{n}=t_{r}+d_{a}-t_{s}
$$

Bağıntıda $t_{r}$, kuyrukta ilk sırada bekleyen sürücülerin ortalama başlangıç tepki süresini (saniye); $d_{a}$, araçların hızlanması süresindeki ortalama gecikme süresini (saniye), $t_{s}$ ise başlangıç kayıp süreyi (saniye) göstermektedir. Hesaplarda kullanılan " $d_{a}$ ” değeri, araçların (çalışmanın bu kısmında araç kavramı birim otomobil değeri olarak kabul edilmiş̧ir) kavşaktan hiç durmadan $50 \mathrm{~km} / \mathrm{saat}$ hız ile geçtikleri kabul edilerek farklı hızlar için hesaplanmış değerlerin ortalamasıdır.

Akçelik v.d. [17] çalışmalarında " $d_{a}$ " değerini 2,8 saniye; $t_{s}$ değerini ise 2,1 saniye olarak kabul etmiştir. Çalışkanelli vd.d [12] aynı kabulü yapmış; ortalama $t_{r}$ değerini 1,39 saniye olarak (4) denkleminde yerine koyduklarında temel doygun akım değerini 1722 araç/saat/şerit olarak hesaplamışlardır. Buna göre, ideal doygun akıma karşılık gelen $h_{n}$ takip aralığının hesaplanmasında iki ana parametre öne çıkmaktadır. Bunlardan birisi, kuyrukta ilk sırada yer alan sürücülere ait başlangıç tepki süresi, diğeri ise kayıp zaman değeridir.

Işıklı bir kavşakta ışığın yeşile dönmesi ile araçlar hareket etmeye başlarlar. Ancak yeşil sürenin başında kuyruğun ilk sıralarında bulunan birkaç araç sinyalin değiştiğini algılayıp hareket edene kadar fazladan bir süreye ihtiyaç duymaktadır. Kuyrukta ilk sırada yer alan bu ilk birkaç aracın gecikmesinden kaynaklanan süreye başlangıç kayıp zaman adı verilir. Özellikle etkin yeşil sürenin hesaplanmasında kullanılan parametrelerden biri olan başlangıç kayıp zaman değeri HCM 2010'da kuyruğun ilk dört sırasında duran araçların fazladan gecikmeye uğrayacağı kabulü ile hesaplanmaktadır [1]. Başlangıç kayıp zaman, araç tipi, eğim; kavşaktaki yaya hareketleri; sürücüden sürücüye değişen reaksiyon süresi; psikolojik faktörler ve kavşak geometrisi gibi birçok faktörden etkilenmektedir.

Başlangıç kayıp zaman süresinin belirlenebilmesi için farklı ülkelerde, çeşitli araştırmacılar tarafından birçok hesap yöntemi önerilmiştir. Bonneson [18] kuyruktaki ilk birkaç aracın istenen hıza ulaşırken nispeten uzun boşalma aralıklarıyla birbirlerini takip ettiğini belirtmiştir. Başlangıç kayıp zamanı, bu ilk birkaç aracın kaybettiği zamanları ekleyerek bulmuştur:

$$
t_{s}=\sum_{i=1}^{Z}\left(h_{i}-\mathrm{h}_{\mathrm{n}}\right)
$$

Burada $t_{s}$, başlangıç kayıp zaman (sn/faz); $h_{i}$, "i." kuyruktaki aracın aralık değeri (sn); Z, $h_{n}$ 'den büyük olan aralığa sahip araçların sayısı olarak ifade edilmiştir. 
McShane v.d. [19] yaklaşımına göre başlangıç kayıp zaman, gözlenen takip aralığı değerleri ile ilk dört aracın ideal doygun takip aralığı değerleri arasındaki farka eşittir.

$$
t_{s}=\frac{\sum_{i=1}^{n} \sum_{j=1}^{4}\left(t_{i j-} h_{n}\right)}{n}
$$

Burada $i$, devre sayısı; $j$, kuyruktaki aracın pozisyonu; $n$, toplam devre sayısı; $t_{i j}$, kuyruktaki her bir aracın takip aralığı olarak tanımlanmıştır.

Çalışma kapsamında incelenen kavşaklar için başlangıç kayıp zaman değeri, McShane v.d. [19] yaklaşımı kullanılarak hesaplanmıştır. Temel doygun akım hesaplarında kullanılan 100 adet farklı devreden elde edilen veriler kayıp zaman değeri hesaplamalarında da kullanılmıştır. Hesaplanan kayıp zaman değerlerine ait tanımlayıcı istatistikler Tablo 4' te verilmiştir.

Tablo 4. Başlangıç kayıp zaman verilerine ait tanımlayıcı istatistikler

\begin{tabular}{|c|c|c|c|c|c|c|c|c|}
\hline Ortalama & $\begin{array}{c}\text { Standart } \\
\text { Hata }\end{array}$ & Medyan & $\begin{array}{c}\text { Standart } \\
\text { Sapma }\end{array}$ & Basıklık & Çarpıklık & Aralık & $\begin{array}{c}\text { En } \\
\text { Küçük } \\
\text { Değer } \\
\end{array}$ & $\begin{array}{c}\text { En } \\
\text { Büyük } \\
\text { Değer } \\
\end{array}$ \\
\hline 2,05 & 0,11 & 1,90 & 1,21 & $-0,35$ & 0,47 & 5,26 & 0,01 & 5,27 \\
\hline
\end{tabular}

Tablo 4'ten de görülebileceği gibi, literatürde genel kabul gören 2 saniye'lik kayıp zaman değerinin, ülkemiz için de geçerli kabul edilebileceği anlaşılmaktadır. Kayıp zaman değerinin ortalamasının 2,05 saniye olmasi; Akçelik v.d. [17] tarafından önerilen ve Çalışkanelli v.d. [12] tarafından da hesaplarda kullanılan 2,1 saniye değerinin kabul edilebilir bir değer olduğunu da göstermektedir.

Yapılan tüm bu değerlendirmeler, Çalışkanelli v.d. [12] tarafindan bulunmuş olan 1,39 saniye'lik başlangıç tepki süresi kullanıldığında bu çalışma kapsamında incelenen kavşaklar için temel doygun akım değerinin $\mathbf{1 7 2 0}$ otomobil/saat/serit olarak kabul edilebileceğini göstermiştir.

\section{TEMEL DOYGUN AKIM DÜZELTME FAKTÖRLERI}

Bir kavşaktaki temel doygun akım değerinin yanı sıra, temel doygun akım değerini ve dolayısıyla kavşak kapasitesini etkileyen diğer faktörlerin de incelenmesi büyük önem taşımaktadır. Bağıntı (3)'ten de görülebileceği gibi literatürde çok sayıda düzeltme faktörü yer almakla birlikte çalışma kapsamında incelenen kavşakların veri toplanan yaklaşımlarında aşağıda belirtilen doygun akım düzeltme faktörü analizleri için yeterli sayıda ve uygunlukta veri toplanamamıştır:

1. Otobüs durağı etkisi (incelenen kavşak yaklaşımlarında 100 metre mesafede otobüs durağı bulunmamaktadır); 
2. Parklanma düzeltme faktörü (gözlem yapılan saatlerde incelenen yaklaşım kollarında araç parkına izin verilmemektedir).

3. Yaya etkisi (İncelenen kavşak yaklaşımlarının bir kısmında yaya hareketi yoktur veya ihmal edilebilecek düzeydedir. Yaya hareketlerinin yoğun olduğu saatlerde, trafik polislerinin trafik akımını yönettiği gözlemlenmiştir. Bu sürelerde yapılan gözlemler, analiz dışı bırakılmıştır).

4. Eğim (eğim değerleri \%1'in altındadır bu nedenle ihmal edilmiştir).

5. Bölge Tipi Faktörü (İzmir'deki kavşakların tümü, Merkez Kent olarak adlandırılan alan içerisinde yer almaktadır. Denizli ve Bursa'daki kavşaklar da kent merkezi içinde bulunmaktadır. Dolayısıyla Bölge Tipi Faktörünün etkisi çalışma kapsamı dışında bırakılmıştır).

6. Şerit kullanım oranı faktörü (Şerit kullanım oranı faktörü HCM 2010'da bir manevra tipi için -doğru geçiş, sola veya sağa dönüş gibi- birden fazla özel/ veya bir manevraya özel olarak ayrılmışş şeritler bulunması durumu için önerilmektedir. $\mathrm{Bu}$ anlamda incelenen kavşaklar arasında sadece tek bir kavşak (Vali konağı) tam anlamıyla bu tanıma uymaktadır. Ancak bu kavşakta, söz konusu etkiyi tanımlayabilmek için kullanılabilecek yeterli veri sayısı bulunmamaktadır).

Sonuç olarak çalışma kapsamında, şerit genişliği, ağır araç etkisi, sola-sağa dönüş manevraları için düzeltme faktörü analizleri yapılmıştır. Bu faktörlerin yanı sıra, 1şıklı yuvarlakada kavşaklar için de bir düzeltme faktörü önerisi getirilmeye çalışılmıştır. İlk aşamada, düzletme faktörleri kısaca irdelenecek ve daha sonra ise düzeltme faktörlerinin parametrelerinin hesaplanmasına geçilecektir.

\subsection{Yaklaşım Kolu Şerit Genişliğinin Doygun Akım Üzerindeki Etkisi}

Şerit genişliği ve doygun akım arasındaki ilişki ile ilgili olarak birçok farklı çalışma yapılmıştır. Bu çalışmaların en önemlilerinden birisi Leong [20] tarafından yapılan çalışmadır. Bu çalışmada, Sidney'de 23 tane sinyalize kavşak yaklaşım kolu incelenmiş ve yaklaşım kolu genişliğinin $2,75 \mathrm{~m}$ ve $3,6 \mathrm{~m}$ arasında değişmesi durumunda şerit genişliğinin doygun akım üzerinde önemli bir etkisi olmadığı bulunmuştur. Abu-Rehmen [21], Chang Chien [22] ve İbrahim vd. [23] gibi araştırmacılar ise, farklı şerit genişliğine sahip kavşaklarda yaptıkları gözlemlerden yararlanarak şerit genişliği faktörü için regresyon analizine dayalı bağıntılar geliştirmişlerdir.

Highway Capacity Manual 2010'da (HCM 2010) [1], şerit genişliklerinin 2,4 m (8 ft) ile 4,8 $\mathrm{m}(16 \mathrm{ft})$ arasında değişebileceği belirtilmiştir. $3,0 \mathrm{~m} \sim 3,9 \mathrm{~m}(10 \mathrm{ft} \sim 12,9 \mathrm{ft})$ aralığında, şerit genişliğinin doygun akım üzerinde bir etkisi olmadığı vurgulanmıştır. 3,0 m' den küçük şerit genişlikleri için düzeltme katsayısı olarak " 0,96 ”, 3,9 m' den daha büyük şerit genişlikleri için de düzeltme faktörü olarak " 1,04 " değeri önerilmiştir.

Çalışmada gözlem yapılan kavşaklardaki şerit genişlikleri 3;0 3;5 metre aralığında değişmektedir. Yapılan gözlemlerden elde edilen doygun akım değerleri ile şerit genişlikleri arasındaki ilişki Şekil 2'de görülmektedir. Şekilden de görülebileceği gibi, doygun akım değeri ile şerit genişliği arasında anlamlı bir ilişki bulunmamaktadır. Bu sonuç, Leong'un [20] çalışmasında ve HCM 2010'da yer alan bulgularla örtüşmektedir. 


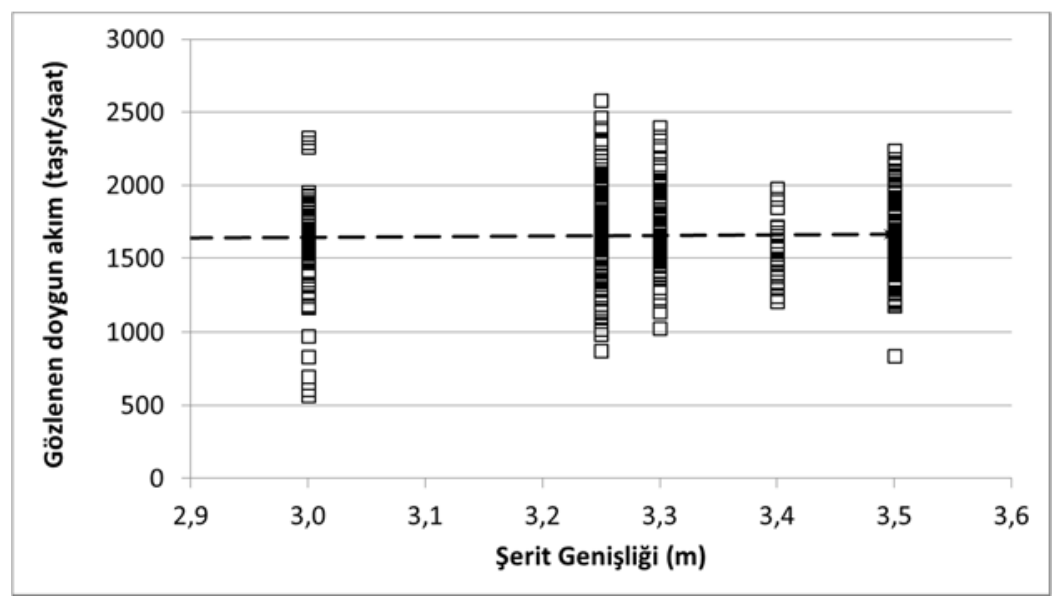

Şekil 2. Şerit genişliği-doygun akım ilişsisi

\subsection{Ağır Araçların Doygun Akım Üzerindeki Etkisi}

Ağır araçlar, fiziksel büyüklüklerinden ve düşük hızlanma ve/veya yavaşlama kabiliyetlerinden dolayı, özellikle kavşaklarda trafik akımını olumsuz yönde etkilemektedirler. Eşdeğer otomobil birimi (EOB) değerleri, ağır araçların trafik operasyonları üzerindeki bu olumsuz etkilerini yansıtabilmek amacıyla kullanılmaktadır.

Eşdeğer otomobil birimi (EOB), mevcut koşullar altında bir ağır aracın trafik üzerinde yaptığı etkinin aynısını yapacak otomobil sayısını veren bir katsayıdır. En basit şekli ile bir trafik akımı içindeki ağır araç sayısı, ağır aracın cinsine (minibüs, kamyon, otobüs v.b.) ait EOB değeri ile çarpılarak ağır araçların trafik üzerindeki etkileri hakkında bir fikir edinilebilir. HCM 2010'da tüm ağır araç türleri (otobüs, kamyon v.b.) birlikte değerlendirilmiş ve tüm ağır araçlar için EOB değeri 2,00 olarak önerilmiştir.

"TS6407 Şehir İçi Ulaşım Hesaplamalarında Kullanılan Araç Tiplerine Göre Otomobil Eşdeğeri Katsayıları" standardında, çeşitli tipteki araçlara ait EOB değerleri verilmiştir (Tablo 5) [24]. Diğer ülkelerde, genellikle ağır araç sınıfına dahi sokulmayan minibüsler, ülkemizde yolcu taşıma amacıyla kullanılmaları nedeniyle ağır araç olarak nitelendirilmektedir. EOB değerlerinden, 1şıklı kavşaklarda incelenen şerit gruplarının doygun akım değerlerinin belirlenmesi amacıyla "ağır araç düzeltme faktörü ( $\left.f_{H V}\right)$ "nün hesaplanmasında yararlanılmaktadır. Ağır araç düzeltme faktörü, genel olarak aşağıdaki şekilde hesaplanabilir [25]:

$$
f_{H V}=\frac{1}{\left(1+\sum_{i} P_{i}\left(E O B_{i}-1\right)\right)}
$$

Burada $P_{i}$, "i" aracının akım içerisindeki yüzdesini; $E O B_{i}$ ise " $i$ " aracının eş değer otomobil birimini ifade etmektedir. 
Tablo 5. TS6407'ye göre eş değer otomobil birimleri [24]

\begin{tabular}{lccc} 
Araç Cinsi & $\begin{array}{c}\text { Şehir İçi } \\
\text { Yollarda }\end{array}$ & $\begin{array}{c}\text { Dönel } \\
\text { Kavşaklarda }\end{array}$ & $\begin{array}{c}\text { Işıklı kontrollü } \\
\text { Kavşaklarda }\end{array}$ \\
\hline $\begin{array}{l}\text { Özel otomobil, taksi, sepetli motosiklet, triportör, } \\
\text { yüksüz 1500kg'a kadar olan pikap }\end{array}$ & 1,00 & 1,00 & 1,00 \\
\hline Minibüs, Dolmuş, Taksi & 1,15 & 1,30 & 1,27 \\
\hline Yüksüz 1500kg'a kadar ağır ticari kamyon, at arabası & 2,00 & 2,80 & 1,75 \\
\hline $\begin{array}{l}\text { Kent içi ve dış1 yolcu otobüsü (körüklü dâhil), servis } \\
\text { otobüsü, troleybüs, tramvay }\end{array}$ & 3,00 & 2,80 & 2,25 \\
\hline Motosiklet, mopet & 0,75 & 0,75 & 0,33 \\
\hline Bisiklet & 0,33 & 0,50 & 0,20
\end{tabular}

\subsection{Sola ve Sağa Dönüş Hareketlerinin Doygun Akım Üzerindeki Etkisi}

Bir ışıklı kavşağın başarımını etkileyen en önemli faktörler arasında, sola ve/veya sağa dönüş yapan araçların oranı ve bu manevrayı yapan sürücülerin davranışları da bulunmaktadır. Özellikle sola dönüş manevrası, karşı yönden gelen trafik akımıyla kesiştiği için ayrı bir faz süresi tanımlanmasını gerektirebilir. Sağa ve sola dönüşlerin incelenmesinde aşağıdaki hususlar dikkate alınmaktadır [16]:

- Sağa dönüşler için

o Sağa dönüşler için özel şerit varlı̆̆

o Sinyal faz türü (korumalı, izinli ya da korumalı \& izinli) [korumalı fazda yayalar ile karşılaşma tamamen engellenmektedir.];

o Yaya geçidini kullanan yaya hacmi;

o Paylaşımlı şeritten sağa dönüş oranı;

o Korumalı fazın korumalı kısmını kullanan araç oranı.

- Sola dönüşler için:

o Sola dönüşler için özel şerit varlığ1;

o Sinyal fazı türü (korumalı, izinli, korumalı \& izinli);

o Paylaşımlı şeritten sola dönüş oranı;

o İzinli sola dönüşlerde karşı yöndeki akım oranı.

Sola ve sağa dönüşler için ayrı bir dönüş şeridi veya cebinin varlığı, bu manevraların, kavşak kapasitesi üzerindeki olumsuz etkilerini en aza indirgemektedir. Korumalı fazların varlığı ise, sürücü davranışlarından kaynaklanan olumsuzlukları (kaza olasılığı gibi) en aza indirmekle birlikte, devre süresini uzattığından kapasitenin azalmasına yol açabilmektedir. Sağa dönüşler, genelde katılım şeklinde gerçekleştiği için birçok uygulamada sürücü davranışları açısından önemli bir sorun yaratmamaktadır. Hatta uygun geometri ve trafik akım koșulları altında, sağa dönüş manevrasına katılacakları akımdaki araçlara öncelik vermek kaydıyla, ayrı bir faz süresi tanımlanmaksızın sürekli olarak izin verilebilmektedir $[1,16]$. 
Sağa ve sola dönüşler için de, ağır araçlara benzer bir bağıntı kullanılabilmesi mümkündür [26]. Buna göre sağ dönüş ve sola dönüş yapan araçlar için de birer EOB önerilmesi uygun olacaktır. Sağa dönüş düzeltme faktörü $\left(f_{R T}\right)$ ile sola dönüş düzeltme faktörü $\left(f_{L T}\right)$ aşağıdaki bağıntılardan hesaplanabilir:

$$
\begin{gathered}
f_{R T}=\frac{1}{1+P_{R T}\left(E O B_{R T}-1\right)} \\
f_{L T}=\frac{1}{1+P_{L T}\left(E O B_{L T}-1\right)}
\end{gathered}
$$

Bağıntılarda, $P_{R T}$, sağa dönen araç oranını; $E O B_{R T}$, sağa dönen araçlara ait eş değer otomobil birimini; $P_{L T}$ sola dönen araç oranını; $E O B_{L T}$, sola dönen araçlara ait eş değer otomobil birimini ifade etmektedir (hesaplarda dikkate alınan sağa ve sola dönen araçlar otomobildir).

Çevik [27] yaptığı çalışmada, 1şıklı bir kavşakta kuyrukta ilk sırada bekleyen aracın sola dönüş yapan bir araç olması durumunda $\mathrm{EOB}_{\mathrm{LT}}$ değerinin 1,02; doğru geçiş yapan bir araç olması durumunda ise 1,04 olduğunu bulmuştur. Canseven [28], Antalya Güllük kavş̧ağından elde ettiği değerlerden, sağa dönen otomobillerin EOB değerinin 1,19 olduğunu hesaplamıştır. Çalışkanelli ve Tanyel [13] ise, sola ve sağa dönüş yapan sürücülerin ortalama başlangıç tepki sürelerinin, doğru geçiş yapan sürücülere oranla daha düşük olduğunu göstermiştir.

\subsection{Işııııı Yuvarlakada Kavşakların Doygun Akım Üzerindeki Etkisi}

Türkiye'de 1şıklı yuvarlakada kavşaklar çok uzun bir süredir kavşak tasarımının önemli bir kısmını oluşturmaktadır. Bu tür kavşaklar, ülkemiz sürücüleri tarafından daha fazla kabul görmekle birlikte, özellikle sola dönüşlerden kaynaklanan depolama alanlarının nispeten kısıtlı olması sebebiyle doğru geçiş yapmak isteyen araçların maruz kaldıkları gecikmelerin beklenenin çok üstünde olması gibi bir olumsuzluğa yol açabilirler. Bununla birlikte kavşak içerisinde araçların birbirlerinin görüş alanını kapatması durumu da söz konusudur. $\mathrm{Bu}$ olumsuzluğu ortadan kaldırmak için kavşak ortasına yerleştirilecek ada çapının, bütün sola dönecek araçları depolayacak şekilde belirlenmesi gerekir [29].

Işıklı kavşaklarla ilgili yapılan çalışmalar dünyada ancak son yıllarda önem kazanmaya başlamıştır. Çalışmaların bir kısmı trafik güvenliği üzerine yoğunlaşırken [30]; bir grup araştırmacı da ışıklı dönel kavşakların sinyal optimizasyonu ve başarımı üzerine çalışmışlardır. Bunlardan Qian ve diğ. [31] tarafından yapılan çalışmada, düzenli ve fazla trafik akımının bulunduğu kavşaklarda araç kesişmesi ve kavşak tıkanıklığı problemlerini ortadan kaldırmak için ışıklı yuvarlakada kavşak uygulamasının etkin bir çözüm olduğunu ortaya koymuşlardır. Bai ve diğ. [32], ışıklı yuvarlakada kavşakta merkez adanın yarıçapı ve devre sürelerinin ortalama araç gecikmesi üzerindeki etkilerini araştırmışlardır. Maher [33], Tracz ve Chodur [34] ve Ma v.d. [35] sinyal sürelerinin optimizasyonu ile kavşaktaki gecikmelerin azaltılması üzerine çalışmalar yapmışlardır. 

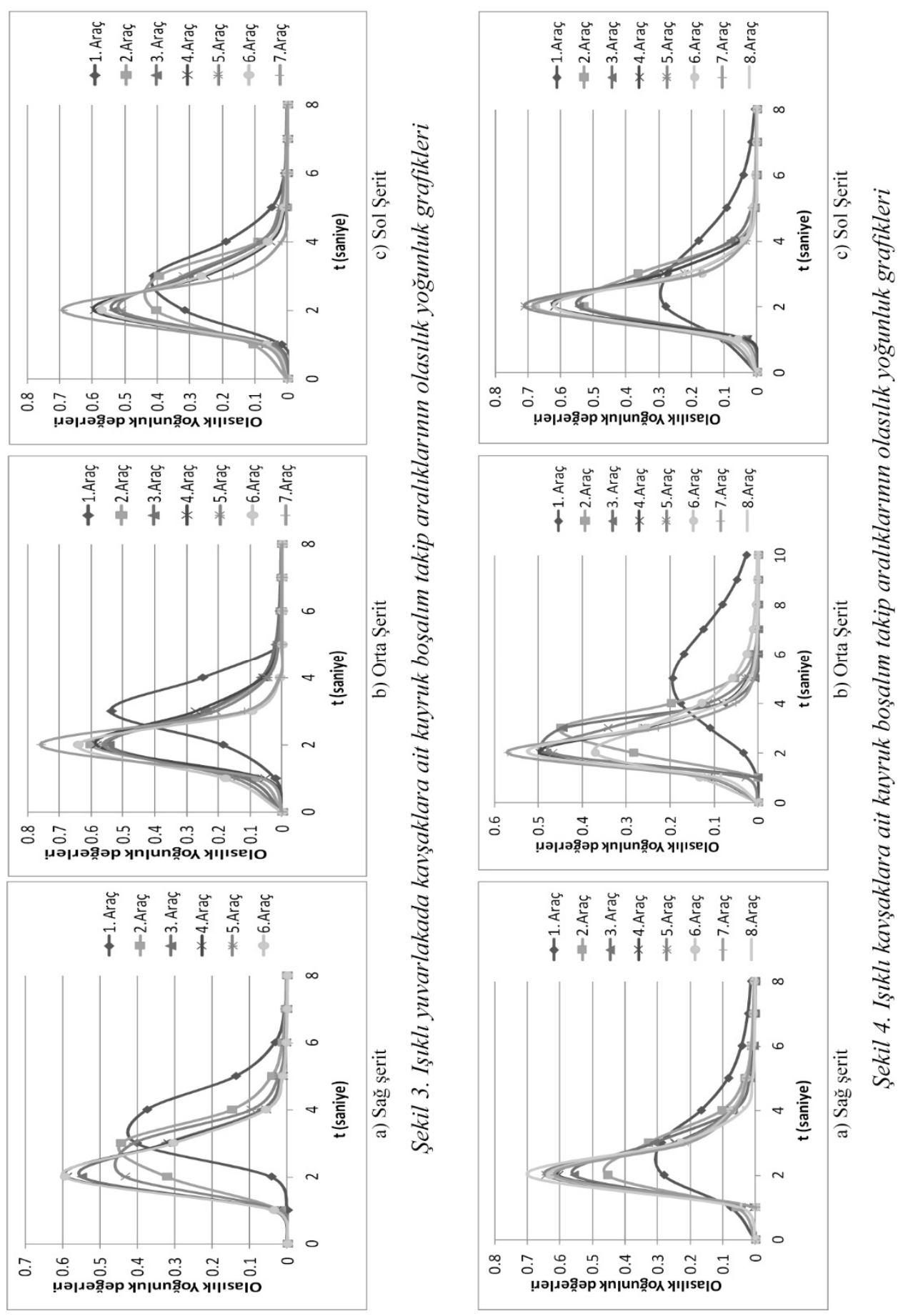
Sinyalize Kavşaklarda Doygun Akım Değerinin İrdelenmesi

Ülkemizde 1şıklı yuvarlakada kavşakların kapasite ve başarımı üzerine yapılmış olan en önemli çalışmalardan bazıları Çakıcı ve Murat $[36,37]$ tarafından yapılmış olan çalışmalardır. Araştırmacılar çalışmalarında, kavşak yaklaşım kollarındaki trafik hacimlerinin ve sola dönüş hacimlerinin artması durumunda ortalama araç gecikmelerinin önemli düzeyde arttı̆̆ı, buna karşılık oluşturulan örnek durumlar için farklı faz planları ve sinyal sürelerinin uygulanması ile birlikte ortalama araç gecikmelerinin önemli oranda azaltılabileceği sonucuna varmışlardır. Bunun yanı sıra, dönüşs şeridi sayısının ikiden üçe çıartılması durumunda, dönüşş şeritlerindeki örülme bölgelerinden dolayı, ortalama araç gecikmelerinin az da olsa arttığını tespit etmiş̧lerdir.

Işıklı yuvarlakada kavşaklarla, diğer ışıklı kavşakların sürücüler tarafından kullanım farklılıkları, kuyruk boşalım takip aralıklarının dağılımları incelendiğinde daha sağlıklı bir biçimde anlaşılabilir. Şekil 3'te, ışıklı bir yuvarlakada kavşağa, Şekil 4'te de diğer 1şıklı kavşaklara ait şerit ve araçların kuyruk pozisyonuna göre kuyruk boşalım değerlerinin olasılık yoğunluk fonksiyon grafikleri görülmektedir.

Şekil 4 incelendiğinde, 1şıklı kavşaklarda sol ve sağ şeritte, 2. araçtan itibaren eğrilerin en sık görülen (mod) değerlerine karşılık gelen tepe noktalarının yaklaşık aynı zaman cinsinden aralık değerine karşılık geldiği söylenebilir. Yine 2. araç'tan itibaren, sıra numarası arttıkça mod'a karşıllk gelen zaman cinsinden aralık değerinin daha fazla görülmesi; diğer bir deyişle, kuyrukta 8 . Sirada bulunan sürücülerin, kuyrukta kendilerinden daha ön siralarda bulunan sürücülere oranla daha kısa aralıklarla öndeki aracı takip etmeleri beklenir. Ancak Şekil 4 incelendiğinde, sol şeritte 5. sırada bekleyen sürücülerin nispeten daha kısa takip aralık değerlerini tercih ettikleri; sağ şeritte 5 . sırada bekleyen sürücülerin ise 6 . ve 7 . Sırada bekleyen sürücülere oranla daha kısa aralıklarla öndeki aracı takip ettikleri anlaşılmaktadır. Orta şeride ait grafikler incelendiğindeyse, sürücülerin takip aralıklarına dair herhangi bir düzen görülmemektedir. Birbirlerinden çok farklı mod değerleri olduğu, ancak bunun yanı sıra eğrilerin bir düzen içerisinde yer almadıkları açıkça anlaşılmaktadır. Bu durum, orta şeritteki sürücülerin, sol ve sağ şeritteki sürücülerden daha fazla etkilendikleri ve kuyruk boşalımı sırasında bu etki sebebiyle çok farklı zaman cinsinden aralık değerleri ile öndeki araçları takip ettikleri söylenebilir.

Işıklı yuvarlakada kavşaklara ait grafikler incelendiğinde ise, orta şeritteki olasılık yoğunluk eğrilerinin 1. araçlara ait olasılık yoğunluk eğrisi hariç, birbirlerine çok yakın oldukları görülmektedir. Sol ve sağ şeritlerde ise 1. ve 2. araçlara ait eğrilerin diğerlerine oranla daha farklı oldukları anlaşılmaktadır. Genel olarak orta şeritteki sürücülerin takip aralıklarının daha düzenli olduğu söylenebilir. Bu sonuç, diğer ışıklı kavşaklardan elde edilen sonuçlardan farklıdır. Bunun sebebinin, ışıklı yuvarlakada kavşaklarda, orta şeritte seyahat eden sürücülerin sol ve sağ şeride oranla, yan yol katılımlarından daha az etkilenmeleridir.

\subsection{Düzeltme Faktörlerinin Parametrelerinin Belirlenmesi}

Doygun akımın hesaplanmasında üç farklı yöntem kullanılmaktadır:

Çarpımsal yöntem $[1,16]$

$S=S_{0} \cdot f_{1} \cdot f_{2} \cdot f_{3} \ldots$

Eklenik yöntem [38]

$S=S_{0}+\Delta S_{1}+\Delta S_{2}+\Delta S_{3} \ldots$ 
ve Birleşik (combined) yöntem [39, 40].

HCM 2010'da [1] çarpımsal yöntemin tercih edildiği görülmektedir. Bu çalışma kapsamında da çarpımsal yöntem kullanılarak düzeltme faktörlerinin parametrelerinin hesaplanması tercih edilmiştir. Ancak, önceki bölümlerde de açıklandığı gibi incelenen kavşaklarda otobüs durağı, parklanma etkisi, yaklaşım kolu eğimi, şerit kullanım oranı faktörü ve bölge tipi faktörü hakkında analiz yapılmamıştır. Ayrıca, Bölüm 4.1'de açıklandığı üzere, şerit genişlikleri ile ilgili bir analiz de çalışmanın bu bölümünde yer almamaktadır. Basit bir yaklaşımla, yukarıda sunulan bağıntılar kullanılarak sinyalize bir kavşağın, doygun akım değeri aşağıdaki bağıntı yardımıyla hesaplanabilir:

$$
S=S_{o} \times f_{H V} \times f_{R T^{\times}} \times f_{L T} \times f_{s y}
$$

(10) bağıntısında yer alan düzeltme katsayılarının hesaplanmasında kullanılacak eşdeğer otomobil birim katsayıları ile azaltma katsayısının hesaplanabilmesi için Excel programında yer alan çözücü seçeneği kullanılmıştır. Excel programının "ç̧özücü” eklentisi "genelleştirilmiş, indirgenmiş gradyan" olarak isimlendirilen, Waren ve Lasdon [41, 42] tarafından geliştirilmiş doğrusal olmayan bir optimizasyon koduna dayanmaktadır. Çözücü kullanılırken, gözlenen değerler ile hesaplanan değerlerin farklarının karelerinin toplamını en küçük (minimum) yapan katsayıları belirlemek hedeflenmiştir.

Çözücü programında ilk aşamada temel doygun akım değeri olarak HCM 2010'da nüfusu 250000'den fazla olan kentler için kullanılan 1900 otomobil/saat/şerit değeri kullanılmıştır. Diğer katsayılar (minibüs, otobüs, kamyon, sağa veya sola dönen araçlar için EOB değerleri) ise "1" olarak alınarak işlemlere başlanılmıştır. Hesaplar sonucunda sapma oranı (deviation ratio) değeri 0,230'dan 0,181'e düşürülmüş ve bu değeri veren katsayılar kullanılmıştır.

Çalışmanın ilk aşamasında, minibüs, otobüs ve kamyon değerleri için farklı EOB değerleri hesaplanması hedeflenmiştir. Ancak yapılan analizler sonucunda, veri sayılarının az olması sebebiyle kamyon ve otobüs için anlamlı EOB değerleri bulunamamıştır. Bu sebeple, otobüs ve kamyon değerleri birlikte değerlendirilmiştir. Minibüsler içinse, anlamlı bir katsayı elde edilmesi mümkün olmuştur.

Çözücü programının çalışması sonucunda, $\mathrm{S}_{0}$ değeri, 1724,65 araç/saat/şerit olarak bulunmuştur. Bu değer, Bölüm 3 'te bulunan değerlere çok yakındır. $\mathrm{S}_{0}$, Bölüm 3 'te önerilmiş olan 1720 araç/saat/şerit olarak sabit bir değer olarak alındığında; incelenen 1şıklı kavşağın bir şeridine ait doygun akım değerinin aşağıdaki bağıntı yardımıyla hesaplanabilmesi mümkündür:

$$
\begin{aligned}
& S=1720 * \frac{1}{1+P_{\text {minibüs }}(1,33-1)+P_{H V}(2,0-1)} * \frac{1}{1+P_{R T}(1,40-1)} \\
& * \frac{1}{1+P_{L T}(0,96-1)}
\end{aligned}
$$

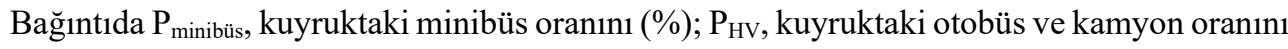
(\%) ifade etmektedir. Bağıntı incelendiğinde, aşağıdaki hususlar ön plana çıkmaktadır: 
Sinyalize Kavşaklarda Doygun Akım Değerinin İrdelenmesi

- Minibüsler, kavşak kapasitesini önemli oranda düşürmektedir. Bunun ana sebebi, özellikle yolcu minibüslerinin kavşak girişlerinde yolcu indirme ve bindirme yapmaları; aynı sebeple yolcu bekleme amaciyla kavşaktan istenenden yavaş geçmeleri ve diğer araçların hareketlerini engellemeleridir. Bu değer, TS6407'de Işıklı Kontrollü Kavşaklarda Minibüs, Dolmuş, Taksi için tanımlanmış olan 1,27 EOB değerine ile de uyumludur.

- Kamyon ve otobüslere ait EOB değerinin, HCM2000 ve HCM2010'da olduğu gibi 2,0 otomobil/ağır araç olduğu anlaşılmaktadır. TS6407'de Işıklı Kontrollü Kavşaklarda Yüksüz 1500kg'a ağır ticari kamyon için tanımlanmış olan 1,75 EOB değeri ile Kent içi ve dışl yolcu otobüsü (körüklü dahil), servis otobüsü, troleybüs, tramvay için tanımlanmış olan 2,25 EOB değeri ile uyumlu kabul edilebilir.

- Hesaplamalar sonucunda karşılaşılan önemli sonuçlardan biri sağa dönen araçlara ait EOB değeridir. Sağa dönüş yapan araçların EOB değeri 1,40 olarak hesaplanmıştır. Hesaplamalarda kullanılan 516 veriden 52 adedi, yuvarlakada olmayan ve sadece otomobillerin sağa dönüş yaptığı devre verisi olarak ayrılmıştır. Bu verilere ait EOB değeri, (8) bağıntısından çekilerek hesaplanmıştır. Hesaplanan sağa dönüşe ait EOB değerlerinin ortalaması 1,38; standart sapmaları ise 0,21 olarak bulunmuştur. Bu sonuç, çözücüden elde edilen sonuçların doğruluğunu da göstermektedir.

- Hesaplamalar sonucunda, sola dönen araçların EOB değeri ise 0,96 olarak bulunmuştur. $\mathrm{Bu}$ sonuç, genel kabullere ters düşmektedir. Ancak benzer şekilde Çalışkanelli ve Tanyel'in [13] çalışmasında, sola dönüş yapan sürücülerin başlangıç tepki süreleri, doğru geçen veya sağa dönen sürücülere oranla daha küçük bulunmuştur. Gözlem yapılan kavşaklarda, sola dönüş için ayrılan yeşil süre, doğru geçiş yapan veya sağa dönen araçlar için ayrılan yeşil süreye oranla daha kısadır. Bunun sonucunda, sola dönüş yapacak sürücüler, sürenin kısalığının da farkına vararak daha hızlı bir şekilde kavşaktan geçiş yapma ve böylece gecikmelerini en aza indirme eğiliminde olabilirler. Bu da, sola dönüşlere ait EOB değerinin küçük olması sonucunu doğurabilir.

Bu çalışmada, ışıklı yuvarlakada kavşakların etkisinin belirlenmesi amacıyla bir düzeltme katsayısı $\left(f_{s y}\right)$ elde edilmeye çalışılmıştır. Yine çözücü programından elde edilen $f_{s y}$ değerinin, “ 0,95 ” olduğu bulunmuştur.

Çalışma sonucunda, sinyalize yuvarlakada kavşakların, doygun akım üzerinde etkili olduğu anlaşılmıştır. Çalışmada 1720 otomobil/saat/şerit olarak önerilmiş olan ideal doygun akım değerinin, sinyalize yuvarlakada kavşaklarda $\% 5$ oranında düştüğü anlaşılmaktadır. Buna bağlı olarak sinyalize yuvarlakada kavşaklar üzerinde yapılacak olan analizlerde ideal doygun akım değeri 1634 otomobil/saat/şerit olarak alınabilir. Bunun yanı sıra, 1şıklı yuvarlakada kavşaklar için bir düzeltme faktörü $\left(f_{s y}\right)$ tanımlanabilir. Bu değer, yukarıda da açıklandığı gibi, hesaplamalarda 0,95 olarak alınabilir.

\section{SONUÇLARIN TEST EDILMESI}

Çalışma kapsamında elde edilmiş olan doygun akım değerleri ile EOB değerlerinin geçerliliklerinin test edilmesi amacıyla aaSIDRA 6.0 programından yararlanılması öngörülmüştür. SIDRA gibi analitik ve ampirik hesap yöntemlerine dayalı analiz programları kullanıcıların kavşak modeline daha fazla hakim olmalarını ve hangi değişkenin ne gibi sonuçlar verebileceğini daha sağlıklı öngörebilmelerini sağlayabilirler. 
aaSIDRA programında, özellikle dönel kavşakların kalibrasyonu (ölçeklendirilmesi) amacıyla bir çevre faktörü tanımlaması yapılmıştır. Çevre faktörü (ÇF parametresi), dönel kavşakların farklı ülkelerdeki kapasitelerinin belirlenmesi için SIDRA standart modelinin kalibre edilmesi amacıyla kullanılmış ve kavşağa ait çevresel koşullarını tanımlayan; hesaplanan kapasite değerlerinde azaltma (yüksek kapasitede) veya arttırma (düşük kapasitede) planlamasının yapılmasına olanak sağlayan bir parametredir. Bu parametre, çalıșma kapsamında " 1 " olarak alınmış; çalışma kapsamında hesaplanan değerler programda ilgili alanlarında kullanılarak hesapların yapılması tercih edilmiştir.

Çalışmada, Karşıyaka Yunuslar, Konak Çankaya ve Bursa Atatürk Lisesi kavşaklarının aaSIDRA modelleri oluşturulmuştur. aaSIDRA programında modelin oluşturulmasında kavşağın geometrisinin doğru oluşturulması büyük önem taşımaktadır. $\mathrm{Bu}$ amaçla aaSIDRA'da farklı alt menülerde veri girişi yapılması gerekmektedir. Şekil 5'te Çankaya kavşağına ait SIDRA çizimi görülmektedir. Şekil 6'da da şerit geometrik özelliklerinin giriş menüsü yer almaktadır.

Konak Çankaya ve Bursa Atatürk Lisesi kavşaklarında ideal doygun akım değeri çalışma kapsamında elde edilmiş olan 1720 otomobil/saat/şerit olarak alınmıştır. Karşıyaka Yunuslar Kavşağı'nda ise 1şıklı yuvarlakada kavşak olması sebebiyle bu değer $\% 5$ oranında azaltılarak 1634 otomobil/saat/şerit olarak programa girilmiştir.

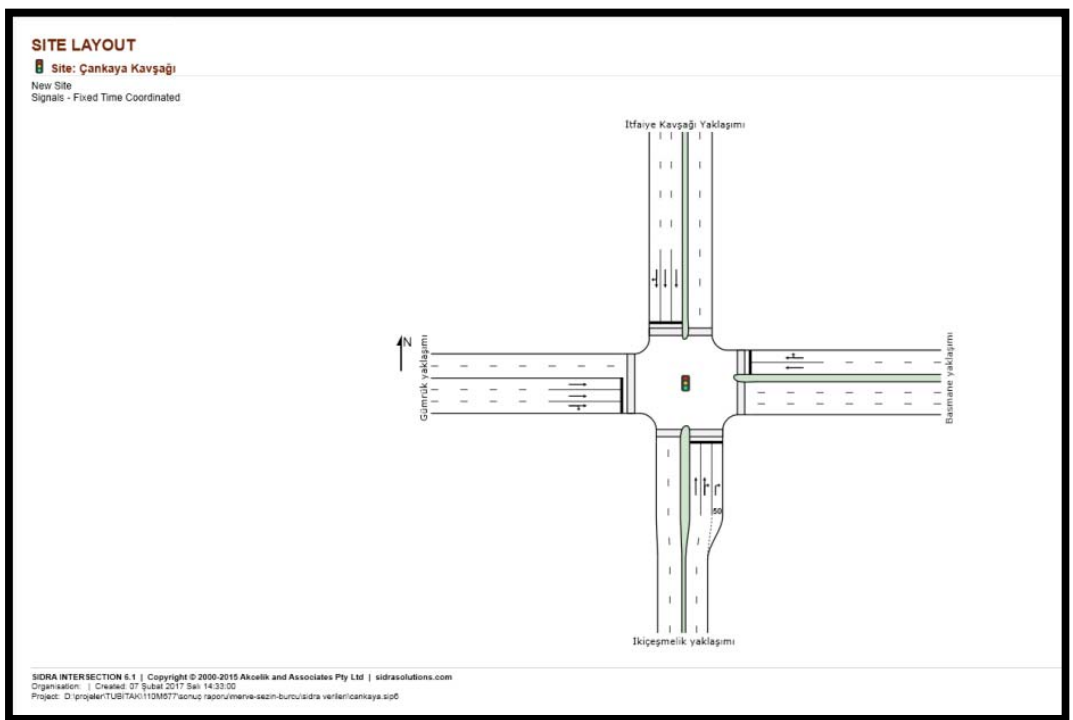

Şekil 5. Çankaya kavşağına ait SIDRA çizimi

Bilindiği üzere SIDRA programı 1şıklı yuvarlakada kavşak seçeneğini içermemektedir. Ancak SIDRA 6.0 programının bir özelliği olarak birden fazla kavşak birleştirilerek bir kavşaklar sistemi oluşturulabilmektedir. Karşıyaka Yunuslar kavşağı, birbirine yakın ve birlikte çalışan yakın mesafeli kavşaklar sistemi olarak modellenmiştir. 
Sinyalize Kavşaklarda Doygun Akım Değerinin İrdelenmesi

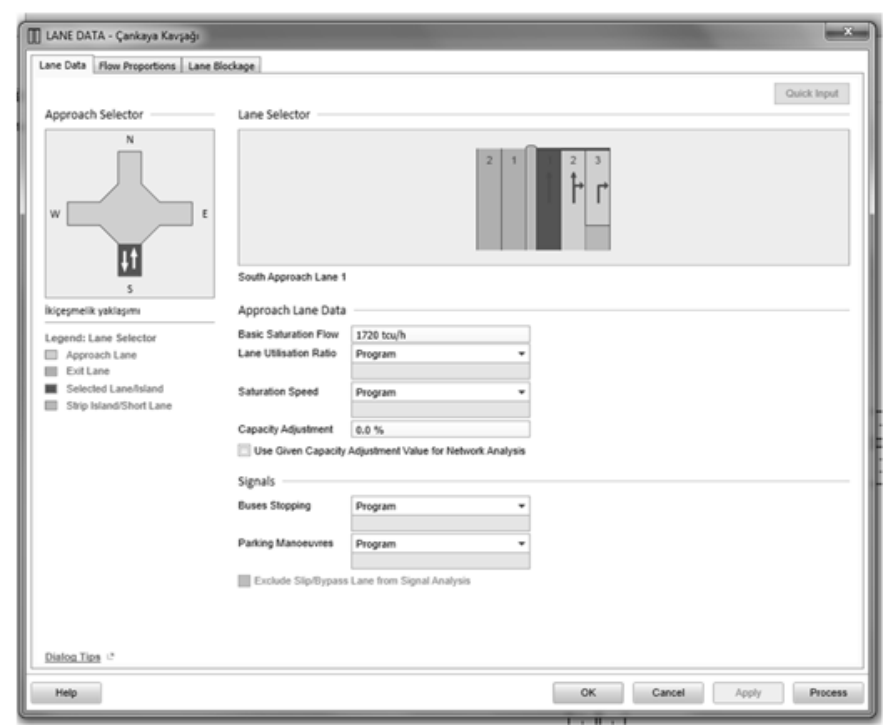

Şekil 6. Şeritlere ait geometrik özelliklerin modele girişi

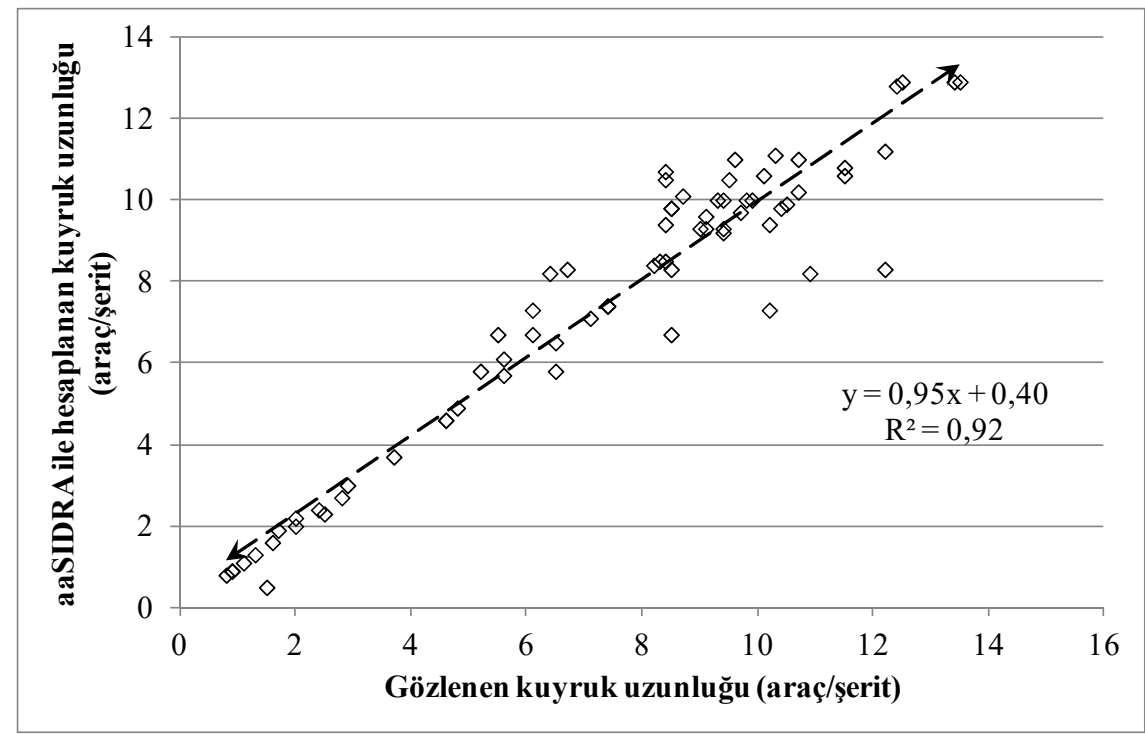

Şekil 7. aaSIDRA ile hesaplanmış kuyruk uzunluklart ile gözlemlenmiş kuyruk uzunluklarının karşılaştırılması.

Sürücü davranışlarının modele yansıtılmasında kullanılabilecek bir diğer değişken de başlangıç kayıp zaman değeridir. Bu çalışma kapsamında kayıp zaman değerinin 0,01 5,27 saniye gibi geniş bir aralıkta değişebildiği görülmüştür. aaSIDRA programı kayıp zaman 
değerini 3 saniye olarak kabul etmiştir. Programda ayrıca bu değerin sadece tam sayı alınabileceği belirtilmektedir. Çalışmada SIDRA programının kabul ettiği değerler kullanılmıştır.

Araçlara ait sola ve sağa dönüş EOB değerleri ise, programa sırasıyla 0,96 ve 1,40 olarak tanımlanmıştır. Minibüsler ayrı bir araç grubu olarak tanımlanmıştır ve EOB değeri 1,33 olarak girilmiştir. aaSIDRA'da ağır araç EOB değeri 1,65; uzun kamyon için ise 2,5 olarak tanımlanmıştır. Ağır araç EOB değeri 2,0 olarak değiştirilmiş̧ir.

SIDRA modellerinde kalibrasyon (ölçeklendirme) kriteri olarak kuyruk uzunluğu seçilmiştir. Ölçeklendirme işlemi için her kavşakta yapılan gözlemlerden yararlanarak 15'er dakikalık veri grupları oluşturulmuştur (15 dakika boyunca kırmızı ışıkta şerit başına kuyrukta bekleyen araçlar sayılarak ortalamaları alınmıştır). Gözlemlenen ve hesaplanan kuyruk uzunluk değerlerinin karşılaştırması, Şekil 7'de görülmektedir. Şekil incelendiğinde programın uygun sonuçlar verdiği anlaşılmaktadır.

\section{SONUÇ VE ÖNERILER}

Çalışma kapsamında, İzmir kent merkezindeki sekiz, Bursa ve Denizli kent merkezlerinde yer alan birer olmak üzere toplam on kavşaktan elde edilen verilerden yararlanarak; ülkemizdeki ışıklı kavşaklar için temel doygun akım değeri ile doygun akımı etkileyen bazı düzletme faktörlerine ait parametreler önerilmeye çalışıllmıştır. Çalışmada aşağıldaki sonuçlara ulaşılmıştır:

- Hesaplamalar sonucunda, temel doygun akım değerinin 1720 araç/saat/şerit olduğu anlaşılmıştır. Bunun ana sebebi olarak, özellikle kuyrukta bekleyen sürücülerin, kuyrukta daha ön sıralarda bekleyen sürücüleri yurtdışındaki sürücülere oranla daha uzun aralıklarla takip etmeleridir.

- Analizler sonucunda 1şıklı yuvarlakada kavşaklar için temel doygun akım değerinin 1634 araç/saat/şerit olduğu hesaplanmıştır. Diğer bir değişle 1şıklı yuvarlakada kavşaklarda; şerit başına doygun akımda yaklaşık \%5'lik bir azalma meydana gelmektedir.

- Çalışmanın diğer önemli bir sonucu, sola dönen araçlara ait EOB değerinin, doğru geçiş̧ yapan araçlardan daha düşük hesaplanmış olmasıdır. Gözlem yapılan kavşaklarda, sola dönüş için ayrılan yeşil süre, doğru geçiş yapan veya sağa dönen araçlar için ayrılan yeşil süreye oranla daha kısadır. Bunun sonucunda, sola dönüş yapacak sürücüler, sürenin kısalı̆̆ının da farkına vararak daha hızlı bir şekilde kavşaktan geçiş yapma ve böylece gecikmelerini en aza indirme eğilimindedirler.

- Çalışmada ayrıca minibüslere ait EOB değerinin 1,33; otobüs ve kamyon gibi ağır araçlar için ise EOB değerinin 1şıklı kavşaklarda 2,0 olduğu bulunmuştur.

Çalışmadan elde edilen sonuçlar ışıklı kavşakların kapasite ve başarım analizinde kullanılan doygun akım değeri ile ilgili önemli bulguları içermektedir. Sonuçlar, ülkemizdeki sürücü davranışlarının diğer ülkelerden önemli oranda farklılıklar içerebileceğini göstermektedir. Ülkemizin farklı kentlerinde ve/veya bölgelerinde yapılacak benzer çalışmalar ile gözlem sayısının artacağı ve ışıklı kavşak performanslarının daha doğru olarak yapılabileceği 
düşünülmektedir..Bu durum ülkemizdeki özellikle büyük kentlerdeki hızla artan trafik sıkışıklığı sorununun azaltılması için yardımcı bir etken olabilecektir.

\section{Semboller}

$b_{S Y} \quad$ : kavşağın sinyalize yuvarlakada olması durumunda kullanılacak azaltma katsayısı,

$d_{a} \quad$ : araçların hızlanması süresindeki ortalama gecikme süresi (saniye),

$E O B_{i} \quad:$ : $i$ " aracının eş değer otomobil birimi

$E O B_{L T} \quad$ : sola dönen araçlara ait eş değer otomobil birimi

$E O B_{R T}$ : sağa dönen araçlara ait eş değer otomobil birimi

$f_{a} \quad$ : bölge tipi faktörü,

$f_{b b} \quad$ : otobüs durağı etkisi düzeltme faktörü,

$f_{g} \quad$ : yaklaşım kolu eğim düzeltme faktörü,

$f_{H V} \quad$ : ağır araç düzeltme faktörü,

$\mathrm{f}_{L p b} \quad$ : sola dönüşler için yaya düzeltme faktörü,

$f_{L T} \quad$ : sola dönüş düzeltme faktörü,

$f_{L U} \quad$ : şerit kullanım oranı faktörü,

$f_{p} \quad$ : parklanma düzeltme düzeltme faktörü,

$f_{R p b} \quad$ : sağa dönüşler için yaya düzeltme faktörü

$f_{R T} \quad$ : sağa dönüş düzeltme faktörü,

$f_{s y} \quad$ : yuvarlakada düzeltme faktörü

$f_{w} \quad$ : şerit genişlik faktörü,

$h_{i}, \quad$ : "i." kuyruktaki aracın aralık değeri (saniye);

$h_{i j} \quad:$ i. devrede, kuyruktaki j. aracın kuyruğu boşaltma takip aralı̆̆ (saniye),

$\mathrm{h}_{\mathrm{n}} \quad$ : ortalama doygun takip aralı̆ğ (saniye)

$i \quad$ : devre sayıs1;

$j \quad$ : kuyruktaki aracın pozisyonu;

$m \quad$ : gözlemlenen devre sayısı

$n \quad$ : toplam devre sayısı;

$N \quad$ : şerit sayıs1,

$n_{i} \quad:$ i. devrede kuyruktaki araç sayısı $\left(n_{i}>4\right)$,

$\mathrm{P}_{\mathrm{HV}} \quad$ : kuyruktaki otobüs ve kamyon oranı 


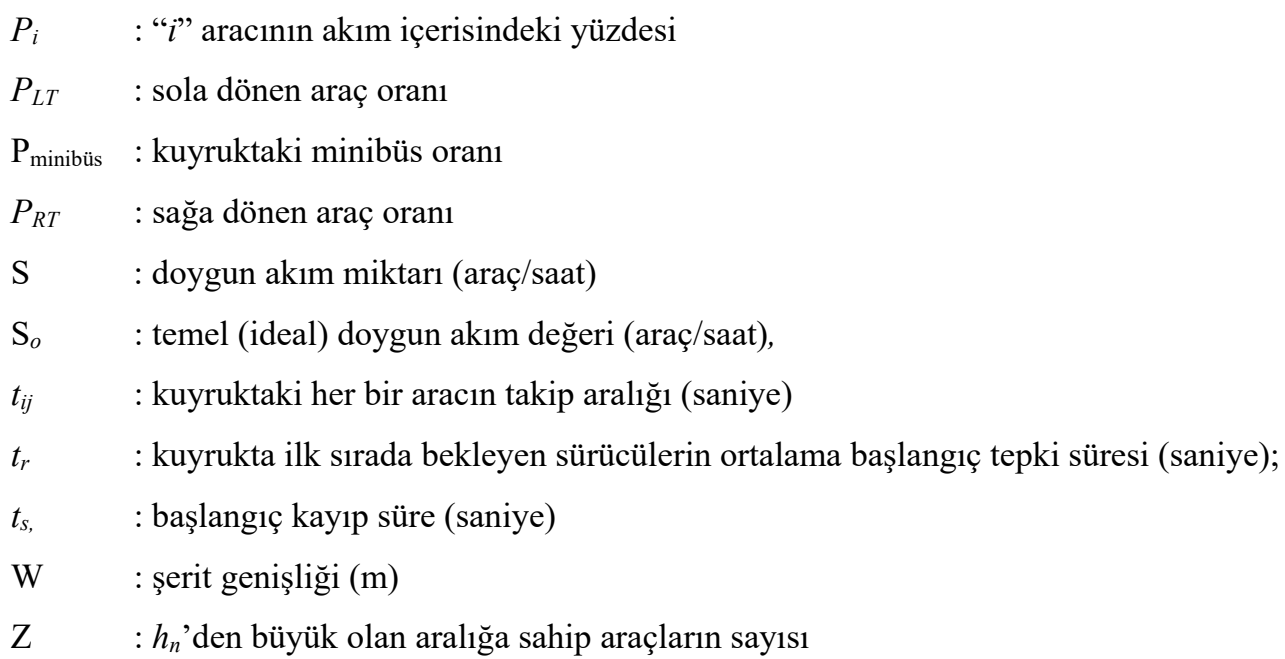

\section{Teşekkür}

$\mathrm{Bu}$ çalışma, Türkiye Bilimsel ve Teknolojik araştırma Grubu'nun desteklemiş olduğu 110M677 no.lu TÜBİTAK projesi kapsamında gerçekleştirilmiştir. Bu çalışmaya verdikleri destekten dolayı TÜBİTAK'a teşekkür ederiz.

\section{Kaynaklar}

[1] Transportation Research Board (TRB), "Highway capacity manual", Washington, D.C., Transportation Research Board, National Research Council, 2010.

[2] Bester, C. J, Meyers, W. L., "Saturation flow rates". In Proceedings of the 26th Southern African Transport Conference (560-568), Pretoria, 2007.

[3] Akova, M., Kavşak sinyalizasyon hesabında duruş, kalkış ve boşaltma koşullarının etkisi, hesap yöntemleri ve ülkemiz gerçeklerine uygun yöntem araştırılması. Doktora tezi, İstanbul: İstanbul Teknik Üniversitesi, 1979.

[4] Murat, Y. Ş. "Sinyalize kavşaklarda bulanık mantık tekniği ile trafik uyumlu sinyal devre modeli", İTÜ, Doktora tezi, 2001.

[5] Nuttymaki, J, Pursula, M., "Saturation flows at signal-group-controlled traffic signals", Transportation Research Record 1572, Paper No: 970233, 1996.

[6] Lin, F. B., Tseng, P. Y., "Fallacies and implications of conventional saturation flow model of queue discharge behavior at signalized intersections", Journal of the Eastern Asia Society for Transportation Studies, 6, pp. 1610-1623, 2005.

[7] Lin, F. B. , Thomas, D. R., "Headway compression during queue discharge at signalized intersection", Journal of the Transportation Research Board, 1920, pp. 81-85, 2005. 
Sinyalize Kavşaklarda Doygun Akım Değerinin İrdelenmesi

[8] Joseph, J., Chang, G. L., "Saturation flow rates and maximum critical lane volumes for planning applications in Maryland", Journal of Transportation Engineering, ASCE 131 (12),pp. 946-952, 2005.

[9] Rahman, M. M., Ahmed, S. N., Hassan, T., "Comparison of saturation flow rate at signalized intersections in Yokohama and Dhaka", Proceedings of the Eastern Asia Society for Transportation Studies, 5, pp. 959-966, 2005.

[10] Çetin, M. Murat, Y. S. Doygun Akımın Belirlenmesinde Sürücü davranışlarına Bağlı Bir Matematik Model, İMO Teknik Dergi, 24 (2), 6399-6414, 2013.

[11] Özdemir, M. "Benefits of Signal Optimization in Isolated Intersections", Boğaziçi University, Institute for Graduate Studies in Science and Engineering, Master of Science Thesis, İstanbu, 2001.

[12] Çalışkanelli S. P., Özuysal M, Figen C., Tanyel S,"Sinyalize Kavşaklardaki Başlangı̧̣ Tepki Süresinin İncelenmesi"10. Ulaştırma Kongresi, İzmir, 167-177, 2013.

[13] Çalı̧skanelli, S.P.; Tanyel, S. Investigating The Driver Response Time at Signalized Intersections, Transport, (Kabul edilmiştir, basım aşamasındadır), 2016.

[14] Tarko, A. P, , Tracz, M., "Uncertainty in saturation flow predictions", Transportation Research Circular E-C018: 4th International Symposium on Highway Capacity, 310$321,2000$.

[15] Greenshields, B. D., Schapiro, D., Ericksen, E. L., "Traffic performance at urban intersections", Saugatuck, Conn., Eno Foundation for Highway Traffic Control, 1947.

[16] Transportation Research Board (TRB)., "Highway Capacity Manual", Washington, D.C. Transportation Research Board, National Research Council, 2000.

[17] Akçelik, R., Besley, M., and Roper, R., UFundemantal relationships for traffic flows at signalized intersections. ARRB TransportationResearch Ltd.,Research Report ARR 340, 1999.

[18] Bonneson, J.A., Study of Headway and Lost time at Single Point Urban Interchanges. Transportation Research Record 1365, TRB, National Research Council, Washington, DC., 1992.

[19] McShane, W.R,. Roess R.P., Basic principles of intersection signalization, Traffic Engineering (2nd Edition), Prentice Hall, Inc. Chapter 16, 1998.

[20] Leong, H.J.W.; Some Aspects of Urban Intersection Capacity, PIVC. 2nd Conf. Austmlian Road Res. Board, 2(1), 305-308, 1964.

[21] Abu-Rahmeh, F.W., Saturation flow and lost time at traffic signals, Ph.D. Thesis Department of Civil and Structural Engineering, University of Sheffield, 1982.

[22] Chang Chien, Saturation Flow at Signal Controlled intersection in Bangkok, MSc Thesis, Asian Institute of Technology, Bangkok, Thailand, 1978.

[23] Ibrahim, W.H.W., Vien, L.L.; Sadullah, A.F.M., Determination of ideal saturation flow at signalised intersections under Malaysian road conditions, Malaysian University Transportation Forum, University of Malaya, Kuala Lumpur: 304-311, 2002. 
[24] Türk Standartları Enstitüsü, TS 6407 Şehir içi ulaşım hesaplamalarında, araç tiplerine göre kullanılacak oto birim katsayıları, Türk Standard, TS 6407, Ankara, 2013.

[25] Kockelman, K. M.; Shabih, R.; Effect of Vehicle Type on the Capacity of signalized Intersections, The Case of Light Duty Trucks, Journal of Transportation Engineering, Vol. 126, No. 6, pp. 516-512, 2000.

[26] Bonneson, J.; Nevers, B.; Nguyen, T.; Fong, T.; "Guideliness for quantifiying the influence of area type and other factors on saturation flow rate", Texas Transportation Institute, Project number: PR9385-V2, Texas, United States, 2005.

[27] Çevik, O.; Sinyalize kavşak yaklaşımlarındaki şerit seçim davranışlarının modellenmesi, DEÜ, Fen Bilimleri Enstitüsü, Yüksek Lisans Tezi, İzmir, 2011.

[28] Canseven, G.; Ağır Araç Oranının Sinyalize Kavşak Kapasitesine Etkisi, Dokuz Eylül Üniversitesi Fen Bilimleri Enstitüsü, İzmir, 2002.

[29] Ayfer, M.Ö., Trafik Sinyalizasyonu, T.C. Bayındırlık Bakanlığı Karayolları Genel Müdürlüğü, Ankara, 1977.

[30] Brabender, B. D.; Vereeck L.; Safety Effects of Roundabouts in Flanders: Signal Type, Speed Limits and Vulnerable Road Users, Accident Analysis \& Prevention, 39 (3), pp. 591-599, 2007.

[31] Qian, H., Li, K., Sun, J.; The Development and Enlightenment of Signalized Roundabout, 2008 International Conference on Intelligent Computation Technology and Automation, 2, Hunan, IEEE, pp. 538-542, 2008.

[32] Bai, Y., Chen W., Xue K.; Association of Signal-Controlled Method at Roundabout and Delay, 2010 International Conference on Intelligent Computation Technology and Automation, 1, Changsha, IEEE, pp. 816-820, 2010.

[33] Maher, M.; The Optimization of Signal Settings on a Signalized Roundabout Using the Cross-Entropy Method, Computer-Aided Civil and Infrastructure Engineering, 23 (2), pp. 76-85, 2008.

[34] Tracz, M., Chodur, J.; Performance and Safety of Roundabouts with Traffic Signals, SIIV-5th International Congress - Sustainability of Road Infrastructures 2012 (Procedia-Social and Behavioral Sciences), 53, pp. 788-799, 2012.

[35] Ma, W., Liu, Y., Head, L., Yang, X.; Integrated Optimization of Lane Markings and Timings for Signalized Roundabouts, Transportation Research Part C: Emerging Technologies, 36, pp. 307-323, 2013.

[36] Murat, Y. S., Cakici, Z., "Statistical Analysis of Vehicle Delay Measurements Considering Different Time Durations", International Civil Engineering \& Architecture Symposium for Academicians (ICESA-2014), 17-20 May, Side-Antalya, 2014.

[37] Çakıcı, Z., Murat, Y. Ş., Sinyalize Dönel Kavşakların Performanslarının Farklı Senaryolar Altında İncelenmesi, 11. Ulaştırma Kongresi, İstanbul, 105-116, 2015.

[38] Kimber, R.M., McDonald, H.; Hounsell, N.B.; The Prediction of Saturation Flow for Road Junctions Controlled by Traffic Signals. TRRL Research Report 67, 1986. 
Sinyalize Kavşaklarda Doygun Akım Değerinin İrdelenmesi

[39] Akcelik, R.; Traffic Signals: Capacity and Timing Analysis. ARRB Research Record 123, Australian Road Research Board, 1981.

[40] Teply, S.; Canadian Capacity Guide for Signalized Intersections: Institute of Transportation Engineers, District 7-Canada and The University of Alberta, 1984.

[41] Waren, A.D., and Lasdon, L.S., "The status of nonlinear programming software", Operations Research, 27(3): 431-456; 1979.

[42] Lasdon, L.S., and Waren, A.D. "Large scale nonlinear programming". Computers and Chemical Engineering, 7(5): 595-604; 1983. 